\title{
Poezja stanu wojennego - poezja
} świadectwa

Anna Skoczek 


\title{
Anna Skoczek
}

\section{Poezja stanu wojennego - poezja świadectwa}

\author{
masz zapisywać fakty \\ masz ocalać pamięć \\ wiersz ma być dokumentem...
}

(Leszek Szaruga, Tylko tak)

$\mathrm{H}$ is toria naszego narodu, pełna tragicznych epizodów, niejednokrotnie nakazywała ludziom pióra: „masz zapisywać fakty”, a ze świadka wydarzeń czyniła autora literackich relacji.

Zwłaszcza dzieje powojennej Polski, obfitujące w zakręty i przełomy, by wymienić rok 1956, 1968, 1970 i lata 1980-81, nakładały na pisarzy takie zadanie. Piśmiennictwo narodowe, oprócz funkcji artystycznych, ewokowało treści etyczne, było też zapisem rzeczywistości, świadectwem czasu. Przeżycia, doświadczenia, wrażenia przechowane w formie dziennika, pamiętnika, listu, wiersza, tworzą literaturę dokumentu osobistego ${ }^{1}$. Poezja i proza, stając się świadectwem czasu, nie traciła swej autonomicznej roli; komentując rzeczywistość, skoro taki był wymóg chwili, pozostawała bliżej życia i bliżej człowieka uwikłanego w zamęt historii.

Stanisław Barańczak z utworów będących wyrazem świadectwa i sprzeciwu ułożył antologię. Pomieścił w niej wiersze poetów polskich z lat 1944-1984 ${ }^{2}$. Dla tego poety i zarazem krytyka literackiego cała polska powojenna twórczość, całe czterdziestolecie, to literatura-świadectwo:

I Określenie Romana Zimanda - por. Stownik literatury XX wieku, red. A. Brodzka, Warszawa 1992, s. 333.

2 Zob. S. Barańczak, Poeta pamięta. Antologia poezji świadectwa i sprzeciwu 1944-1984, Londyn 1984. 
Dając świadectwo naszym czasom i wyrażając sprzeciw wobec niesprawiedliwości czy obłędu, poezja nie przyjmuje bynajmniej cudzych funkcji za swoje, ale spełnia właśnie te, do których ona najbardziej — z racji swojej jednostkowej, konkretnej i antysloganowej natury — jest powołana. Ktokolwiek marzy dziś o powrocie do „poezji czystej”, zapomina nie tylko o tym, że rzeczą nie całkiem czystą jest pisać "poezję czystą" w brudnych czasach, ale i o tym, że tak naprawdę poezja czysta nigdy chyba nie istniała. Nie pisał jej w każdym razie ani Dante, ani John Donne, ani Goethe, ani Norwid. Poezja nie istnieje bowiem bez doświadczenia i choćby wszelkimi sposobami starała się od niego uciec, wzlatując w rozrzedzone powietrze abstrakcji, całą swoją siłę czerpie $z$ dotknięcia ziemi. A skoro codziennym doświadczeniem na naszej ziemi i w naszej epoce jest doświadczenie przemocy i fałszu - również i w tym wypadku zamiast pokładać nadzieje w ucieczce, sensowniej jest obrócić doświadczenie w źródło siły ${ }^{3}$.

Pierwszymi w powojennej literaturze polskiej, którzy wystapili przeciw fałszowaniu rzeczywistości, byli poeci Nowej Fali. Diagnozując sytuację, określili ją mianem kryzysu języka i zgłosili postulat „mówienia wprost”. Lingwizm okazał się nie tylko sposobem pisania; określał także postawę moralną twórcy wobec świata.

Zakręt historii w 1981 roku ponownie postawił wobec poety, ale także wobec zwykłego człowieka, imperatyw „mówienia wprost” i zaświadczania o prawdzie.

$$
\begin{aligned}
& \text { przestałeś być poeta } \\
& \text { jesteś tylko świadkiem } \\
& \text { mów suchymi zdaniami } \\
& \text { bez ozdób bez metafor } \\
& \text { zastrzeleni górnicy } \\
& \text { tobie swój głos oddali } \\
& \text { tylko tak mogą mówić } \\
& \text { tylko tak mogą krzyczeć }
\end{aligned}
$$

$$
\text { (Leszek Szaruga, Tylko tak) }
$$

Wiersz ten określa zadania poety, głosi służebność poezji wobec życia i doświadczenia ludzkiego. Aby wyrazić zło i krzywdę, nie potrzeba pięknych słów, ani „ozdób” czy „metafor”, wystarczy przekazać prawdę. Zabrać głos w imieniu bezimiennych ofiar, także zastrzelonych górników, jak to się stało w przypadku pokolenia poetów stanu wojennego, to nie tylko etyczna powinność człowieka, to także posłannictwo literatury. Widzimy więc, że również twórczość literacka lat 80., podobnie jak Nowa Fala, nawiązuje do romantycznej koncepcji pojmowania literatury jako swoistej misji narodowej i społecznej. Okolicznościowa poezja

\footnotetext{
${ }^{3}$ S. Barańczak, Poematy dla doroslych, op. cit., s. 9.
} 
stanu wojennego jest także tego przykładem. Posiadanie ulotki z odbitym na powielaczu wierszem już graniczyło z bohaterstwem. Cierpliwe przepisywanie przez kolejnych kopistów i przekazywanie tekstów najpierw w rodzinie, później gronie przyjaciół, na koniec ludziom, będącym, jak przypuszczano, po „tej samej stronie”, było działaniem konspiracyjnym i stało się formą walki z wrogiem.

Wówczas każdy wiersz był jak komunikat z pola walki. Tym bardziej, że nie było jeszcze komunikatów. Czytaliśmy łapczywie te wierszowane zapiski o zdarzeniach z pierwszych dni i tygodni stanu wojennego, cieszyliśmy się z ludowej rubaszności wielu autorów, bawiły nas stylizacje na pieśni dziadowskie i parodie znanych tekstów, wzruszały nas zapisane w tych wierszach patos i cierpienie, cieszyło rozszyfrowanie autorstwa anonimowych tekstów napisanych przez zawodowych poetów. Wówczas każdy wiersz był jak promyk nadziei, tym bardziej, że nie było żadnej nadziei. Czytaliśmy więc te wiersze bardziej jako świadectwo duchowe oporu przeciw wojnie komunistów z solidarnością niż jako utwory artystyczne, bardziej jako zapisy stanu duchowego jednostek niż jako teksty kandydujące do arcydzieł polskiej poezji ${ }^{4}$.

Okolicznościowa poezja stanu wojennego jest świadectwem tamtego czasu, jest także świadectwem zbiorowego przeżycia. Wprowadzenie stanu wojennego wywołało uczucia zdumienia, niedowierzania, szoku, trwogi, rozpaczy, złości, żalu. Anonimowe tomiki stanu wojennego są tego przykładem.

\section{Spectrum historyczne}

$\mathrm{Na}$ plan pierwszy w naszych rozważaniach o poezji tego czasu wysuwa się spectrum historyczne, ważne z punktu widzenia pokoleń młodszych, dzisiejszych licealistów, dla których takie pojęcia jak cenzura, ZOMO, WRON, Stocznia Gdańska, kopalnia "Wujek” brzmią obco i nie mają żadnego specjalnego znaczenia lub sens ich jest zgoła odmienny, od tego, który poruszał sumieniami w roku 1980 i 1981, jak w przypadku słowa "Solidarnośc”.

$\mathrm{Z}$ utworów pomieszczonych $\mathrm{w}$ antologiach wierszy wojennych można odtworzyć swoiste kalendarium wydarzeń.

\section{3 grudnia 1981}

Tekstów zawierających datę 13 grudnia jest w omawianych tomikach znakomita większość 5 . Data 13 grudnia pełni funkcję informacyjną:

\footnotetext{
${ }^{4}$ Pseudonim [W. Bolecki], Cóż po poecie w czasie marnym. Przegląd tomików poetyckich stanu wojennego, „Wezwanie" 1982, nr 1, s. 70.

s Antologie: Zielona wrona, Glosy zza muru i Anonimowa poezja stanu wojennego. Siekiera Motyka Smok wawelski zawierają ich około 20 , ale może ich być znacznie więcej.
} 
Trzynastego grudnia roku pamiętnego

Rozpoczął się okres stanu wojennego

Trzynastego grudnia roku pamiętnego

Doczekaliśmy się stanu wojennego

13 grudnia urasta także do rangi symbolu narodowej tragedii i najazdu wroga. Nie stwierdza się jednoznacznie, czy agresorem jest obcy najeźdźca; tak jest w części utworów:

Trzynastego grudnia

roku pamiętnego

WRON napadł na Polskę

z kraju sąsiedniego

czy też najeźdźca jest „swój” wróg, przez co stan wojenny zyskuje wymiar walk bratobójczych:

Trzynastego grudnia roku pamiętnego

napadł wróg na Polskę z narodu własnego.

Polskie dziś mundury miast znienawidzonych,

bagnet wymierzony w Naród swój skrwawiony.

W tomikach okolicznościowej poezji stanu wojennego występują oba te przekonania. Jest też grupa utworów, która łączy te dwa stanowiska. Autorzy wierszy dowodzą, że władze polskie działały pod dyktando radzieckie, stąd obecny w wierszach motyw zdrady:

Trzynastego grudnia roku pamiętnego,

Wróg nie musiał przybyć z kraju sąsiedniego,

Bo on tu na miejscu, w Polsce się znajdował,

Jedną dłoń wyciągal, drugą cios szykowal,

I działając podle na rozkaz sowiecki,

Zrobił okupację na sposób niemiecki.

Sejm, co niby polski, przez Gierka wybrany,

Na swą hańbę wieczną zatwierdza kajdany.

Krótka była wolność, pod pałkami kona,

Szarpie naród polski bolszewicka WRONa.

Pędzą nas ubeki do katorżnej pracy,

Siedzą po więzieniach najlepsi Polacy.

W wierszu znajdujemy także aluzje do obrad sejmu, który zatwierdził wprowadzenie w Polsce stanu wojennego, i do fali aresztowań Polaków, jaka miała wówczas miejsce. 


\section{6 grudnia 1981}

Osobna grupa tekstów jest związana z wydarzeniami w kopalni „Wujek”. Pacyfikacja kopalni "Wujek” na Śląsku rozpoczęła się 16 grudnia o godzinie $10.10^{6}$. Zginęło siedmiu górników. Poświęcono im wiersze: Pieśn o siedmiu, Pamięci siedmiu z „Wujka” (tytuł ten podaje Anonimowa poezja stanu wojennego) znany bardziej pt. Idq pancry na „Wujek”, Pamięci górników zabitych w kopalni „Wujek” $w$ Polsce $w$ grudniu 1981 oraz Polegtym, Synku kto cię zastrzelit, Zabici z kopalni „Wujek” już nigdy nie wyjda, Modlitwa górników kopalni „Wujek” (dostępne tylko w internecie ${ }^{7}$ ).

Najsłynniejszy, obecny w prawie wszystkich tomikach stanu wojennego, a teraz również w internecie, jest utwór Idq pancry na „Wujek”:

Przyszli nocą w uśpiony dom,

Zabierali nas chyłkiem jak zbóje

Drzwi zamknięte otwierał łom

Idą, idą pancry na „Wujek”

Tragedii w kopalni „Wujek” dotyczy także utrzymany w konwencji dziecięcego lamentu List do generata:

\section{Szanowny Panie Generale!}

Mój ojciec umarł miesiąc temu.

W kopalni "Wujek" po postrzale.

A siostra ciagle pyta - czemu?

\section{8 grudnia 1981}

W tym dniu, o godzinie 19.35 został przerwany najdłużej trwający strajk w kopalni „Piast” $\mathrm{w}$ Tychach. Był to tym samym ostatni dzień robotniczego protestu w całej Polsce. Upamiętnia go wiersz Jakuba Brońca (pseudonim Jana Michała Zazuli - autora z Krakowa), śpiewany przez Jana Krzysztofa Kelusa Ostatnia szychta na KWK Piast ${ }^{8}$ :

Wyjeżdżajcie już chłopcy od Piasta

Pora chłopcy opuścić tę dziurę,

Baby płaczą, napiekły wam ciasta,

Zlota klatka uniesie was w górę.

Wiersze: Ostatnia szychta..., Ida pancry... oraz List do generata dotykają wydarzeń rozgrywających się na Górnym Śląsku, tworzą tryptyk. Motywem scalającym jest śmierć górników w kopalni „Wujek”. W ostatnim wierszu wskazują na to słowa: „Żona z «Wujka» ma czarną

6 Zob. Kompleks slaski, Kraków 1984, s. 30.

7 Zob. http://krakwom.bci.net.pl/ludzie/zwoje/zwoje04/text05a.htm

${ }^{8}$ Wiersz zostal przywołany w 17. rocznicę stanu wojennego na łamach „Gazety Wyborczej” 1998, nr 292, s. 1. 
sukienkę". Oprócz perspektywy historycznej czy wręcz dokumentalnej, obecnej w tych tekstach, został wyeksponowany motyw ofiary $i$ kata. Ten prosty schemat, banalna antynomia, tyle razy już w liryce wykorzystywana, pozwala przeciwstawić potędze władzy bezbronność robotników oraz ich rodzin, uwypuklić autentyzm faktów i istotę wydarzeń z 13 grudnia 1981 roku. Czołgi, gazy łzawiące i pały milicyjne naprawdę zostały skierowane wtedy przeciw bezbronnym: robotnikom, studentom, uczniom. Antynomia kata - władzy i ofiary — ludu pozwoliła autorom tych wierszy wyjść poza konflikt polityczny i odsłonić konflikt moralny, rozgrywający się pomiędzy siłą i przemocą a bezbronnością i pokojem. Nie ma w tych wierszach chęci zemsty, nienawiści, jak w typowej proletariackiej liryce (na przykład Władysława Broniewskiego); jest cichy ton skargi, żalu, bólu, utraconych nadziei. Przejmujący ton skargi wypowiedzianej w formie naiwnych pytań dziecka w Liście do generata przemawia swą autentycznością:

Ja jestem dzielny, choć mi smutno

A siostra ma pięć lat dopiero

I nie wie, czemu Pan chce z Polski

Zrobić ojczyznę wdów i sierot.

Pytania dziecka dotyczą także prozaicznych spraw, charakteryzujących jednak rzeczywistość dnia codziennego okresu stanu wojennego:

Dlaczego nie ma butów, książek?

Dlaczego głodni spać idziemy?

Motyw „czystych rąk” („Gdzie twoje czyste ręce generale” - wiersz Ida pancry), opluwania („Trzech oplują wieczorem w dzienniku” — Ostatnia szychta), pojmania („Mamę zabrali wprost z ulicy" - List do generala) ewokują treści ewangeliczne: aresztowania Chrystusa, znieważania go oraz umycia rąk przez Piłata (Ewangelia św. Mateusza 27, 24-25) ${ }^{9}$.

\section{5 stycznia 1982}

Data ta kładzie się cieniem na historię polskiego parlamentaryzmu, tego dnia bowiem sejm zatwierdził uchwałą fakt wprowadzenia w Polsce stanu wojennego. W odróżnieniu od pamiętnego sejmu niemego, obecna sesja odbywała się w atmosferze aplauzu i aprobaty dla decyzji generałów. Zachowane wiersze: Sejm się bawi, W Warszawie na Wiejskiej, Raz na trybunę Izby Wysokiej... są ironiczną ocena postawy posłów i eksponują motyw zdrady narodu. Najbardziej znienawidzonym parlamentarzystą okazał się popularny dotąd pisarz Janusz Przymanowski:

\footnotetext{
${ }^{9}$ Zwrócił na to uwagę Mieczysław Inglot: Struktura ekspresji artystycznej w poezji ulotnej stanu wojennego (na przykladzie wybranych utworów), w: Literatura i Kultura Popularna, t. III, red. J. Kolbuszewski i T. Zabski, Wrocław 1992, s. 112-113.
} 
Krew robotnicza się leje

Generał opór dławi

A Sejm się śmieje

A Sejm się bawi.

Chleba nierzadko brakuje

W kolejkach czas się trawi

ZOMO na ludzi poluje

A Sejm się bawi.

Beztroska sesja się toczy

Klaszczą przekupne posły

Bo bawi ich błazen stary

Towarzysz Przymanowski

(Sejm się bawi)

\section{1 maja 1982}

W tym dniu, upamiętniającym Święto Pracy, odbywały się demonstracje uliczne. Zgromadzeni pozdrawiali się znakiem V (Victorii, zwycięstwa). Skandowano różne hasła np. „Polska to my”, „Precz z reżimem”. Poeta podpisany pseudonimem Wigura pozostawił wiersz: „Pierwszego maja znów wyjdziemy/Naszym pochodem — robotniczym”. Zachował się też utwór 1 Maja 1982 nawiązujący do aktualnej sytuacji. Autor dostrzega fałsz i obłudę członków aparatu partyjnego, którzy odświętnie ubrani zasiedli na trybunach, by obchodzić robotnicze święto, oklaskują mówców na znak zgody i aprobaty, akceptują prowadzoną przez nich politykę, podczas gdy ludzie pracy znajdują się w więzieniach. 1 Maja został przedstawiony jako święto propagandowe, obce robotnikom:

Majowe święto, czerwone święto

W kalejdoskopie się zmienia

Świętują dzisiaj go towarzysze

Bo robotnicy - w więzieniach

\section{3 maja 1982}

Manifestacje patriotyczne, domagające się przywrócenia wolności i powrotu do tradycji święta narodowego obchodzonego w rocznicę uchwalenia Konstytucji z 1791 roku, miały miejsce w trzecim dniu maja. Odbywały się wtedy uroczyste msze święte. Uczestników tych spotkań rozgramiały oddziały milicji i ZOMO. Zdarzały się przypadki ciężkich pobić, skazań na kolegium do spraw wykroczeń, zatrzymań. „Wolno płyną dni pięknego maja” — powie anonimowy poeta w swym wierszu:

Choć zabrano nas siłą od rodzin

Pozbawiono nas prawa i pracy 
Pamiętajcie, Wy tam na wolności

Że myślimy jak WOLNI POLACY

\section{3 maja 1982}

13 dnia każdego miesiąca w wielu kościołach na terenie całego kraju odprawiano msze za ojczyznę. 13 maja 1982 roku szczególnie bezwzględnie rozprawiono się z uczestnikami mszy w Kościele Mariackim w Krakowie. Na wychodzących z kościoła czekały oddziały ZOMO. Uciekający studenci schronili się w Collegium Witkowskiego przy ul. Gołębiej. Do gmachu wrzucono gazy łzawiące, wrzucano je także do tramwajów jadących wokół Plant, przypuszczając, że część manifestantów nimi odjechała. Wydarzenia te upamiętnia wiersz sygnowany datą 13 V 1982 i inicjałem A. P.

\section{W Glównym Rynku w Krakowie...}

Szli w pochodzie od Mariackiego

Obok Wieszcza ku płycie Kościuszki

I śpiewali marsza Dąbrowskiego

I „Rotę" i „Boże coś Polskę"

W niebo wzbił się głos silny jak dzwon

Solidarność! i Wolność dla Polski!

A żołdactwo już chwyta za broń

W imię władzy robotniczo-chłopskiej

Jeszcze słychać: Niech żyje Wałęsa!

Komuś w piersi załamał się głos

Już na czoło naciera ciemiężca

Bratobójczy zadając mu cios

Widzę z boku - ZOMO szaleje

Tnie na oślep co w ręce dostanie

Ktoś ucieka, ktoś pada i mdleje

Słychać okrzyk: no bij esesmanie!

Jadą A-B posiłki dla ZOMO

"Suki”, „scoty” i kto wie co jeszcze

Pierwszy szereg od pompy szturmują

Pozostałych zaciskają w kleszcze.

W Głównym Rynku ludowa łapanka

Pełne budy wracają do bazy

Kraków znów ma ober Hansa Franka

Zomoszkopów i „gapy” rozkazy 
Telewizja nada swój epitet

Ze pijane antyelementy

Chciały spalić partyjny komitet

Ale w porę zostały przymknięte.

Warto zwrócić uwagę na leksykę tego utworu, związaną z okresem okupacji hitlerowskiej: łapanka, Hans Frank, gapa, także neologizmy proweniencji hitlerowskiej: zomoszkopy. Są one świadectwem świadomości Polaków tego czasu; stan wojenny przez wielu był utożsamiany z wojną - II wojną światową. Ostatnia zwrotka natomiast jest aluzją do kłamliwej wersji wydarzeń, podawanej w prasie, radiu i telewizji po manifestacjach.

\section{4 maja 1982}

Maturzysta Grzegorz Przemyk, syn inwigilowanej opozycyjnej poetki Barbary Sadowskiej, został aresztowany przez milicję na Placu Zamkowym w Warszawie i brutalnie pobity na komisariacie, w wyniku czego zmarł. W krążącej obocznie wersji wydarzeń przyczyną śmierci Przemyka były rany, odniesione podczas ataku oddziałów ZOMO:
Młodzież z Warszawy, młodzież z okolic
Dzisiaj zomowcy użyli broni
Maja pięknego dnia 14-tego
Niewinny Grzegorz padł.

Pierwszy i ostatni wers jest nawiązaniem do Ballady o Janku Wiśniewskim z 1970 roku. Informacja o czasie zdarzenia, data wpleciona w tok mowy wiązanej świadczy o tym, że w intencji autora-nadawcy tekst ten miał być świadectwem zbrodni czy szerzej historii, jak to ma miejsce także w innych utworach stanu wojennego. Grzegorzowi Przemykowi został poświęcony również wiersz Pamięci G. Przemyka oraz Dzwony żatobne dzwoniq̨ na trwogę, który opisując przeżycia i ból matki w sposób szczególny nawiązuje do średniowiecznego Lamentu świętokrzyskiego. Jest to nawiązanie nie tylko w sferze tematycznej, ale także leksykalnej: „Pobili Cię synku podle, płacze twa matka”, „O Boże ratuj niewinne dzieci!”.

\section{3 października 1982}

Tego dnia w Nowej Hucie został zastrzelony 19-letni pracownik Huty im. Lenina (dziś Tadeusza Sendzimira) Bogdan Włosik. Jego śmierć, podobnie jak śmierć Ryszarda Smagura, Grzegorza Przemyka czy późniejsza ks. Jerzego Popiełuszki stała się symbolem przemocy i ofiary. Okolicznościowa poezja stanu wojennego utrwala to zdarzenie, świadczy o tym wiersz Pamięci Bogdana Wtosika i Bogdan („Nie wrócił na noc do domu”) ks. Tadeusza Zaleskiego-Isakowicza ${ }^{10}$. W wierszu Pamięci Bogdana Wtosika znajdujemy aluzję do sprawcy jego śmierci:

\footnotetext{
10 Wiersz ten zamieszcza ówczesna prasa. Zob. „Hutnik”. Pismo członków NSZZ „Solidarność” HiL, 1985, nr $17 / 112$ z dnia $5 \mathrm{XI}$, s. 1 .
} 
Wskazałeś palcem Twoim braciom

Gdzie swego mają szukać wroga.

Młodego robotnika zabił kpt. Augustyn, sąsiad z bloku, gdy go Włosik rozpoznał i wskazał jako funkcjonariusza Służby Bezpieczeństwa. Szczególną wymowę mają słowa pomieszczone na końcu tego samego wiersza:

I pozostało echo strzału

I bruk krwią Twoją zbroczony.

Imię, nazwisko, miejsce, data -

zapamiętamy.

\section{Spectrum dokumentalistyczne}

Lektura tomików poetyckich stanu wojennego dostarcza informacji o obozach odosobnienia, losie internowanych i specyfice życia obozowego, a także nastrojach tych, co pozostali za murami ${ }^{11}$. Na tej podstawie można odtworzyć geografię miejsc odosobnienia.

Na mapie tej znajdują się jedne z najcięższych — obozy Śląska: Zabrze-Zaborze, Jastrzębie-Szeroka, Komenda Wojewódzka Milicji Obywatelskiej w Katowicach. Hymn Zaborza, będący kontrafakturą pieśni My Pierwsza Brygada, powstał w Zabrzu-Zaborzu, obozie istniejącym od 13 grudnia 1981 do 3 lipca 1982 roku (po krótkiej przerwie czynny był do końca stanu wojennego). Tu został napisany wiersz Idq pancry na Wujek, na taśmę nagrano go w obozie w Uhercach ${ }^{12}$.

W obozie w Glogowie, istniejącym od 13 grudnia 1981 do 30 sierpnia 1982 roku, śpiewano Modlitwę internowanych $w$ Glogowie, w Opolu natomiast, gdzie internowani przebywali stosunkowo krótko, bo w dniach od 13 grudnia 1981 do 9 stycznia 1982 roku, powstała kontrafraktura pieśni rewolucyjnej Szlachta w roku 1831 Gustawa Ehrenberga i zza murów unosił się głos: „Gdy naród po latach zapragnął wolności, partyjni w stolicy radzili”.

Odrębną grupę stanowią obozy dla internowanych w Bieszczadach: Nowy Eupków (od 20 marca do 23 grudnia 1982 roku) i Uherce (powstał w lutym 1982, istniał do grudnia tego roku), także Arłamów, gdzie przebywał Lech Wałęsa. Znany jest Hymn internowanych $w$ Uhercach oraz pieśn $W$ Bieszczadzkich tagrach. Niedaleko, w Rzeszowie-Załężu istniał kolejny obóz, czynny od 13 grudnia 1981 do 28 września 1982 roku. Zachowała się Pieśń internowanych w Załężu, znana także jako Kolęda internowanych („Pociesz Jezu kraj płaczący” — w antologii Noc generatów znajdujemy informację, że kolędę tę napisano w Nowym Wiśniczu). W Załężu zimą 81/82 powstała także pieśń góralska:

"Zob. Glosy zza muru. Wiersze i piosenki z ośrodków odosobnienia dla internowanych (grudzień - listopad '82), Polska, listopad 1982.

${ }_{12}$ Zob. Gtosy zza muru, op. cit., s. 21. 
Choćbyś Wojtek sto dekretów wyrychtowal, Choćbyś syćkich śwarnych chłopów internował -

Solidarność nie zginie w góralskiej dziedzinie,

Nie ty będzies nam góralom harnasiował.

Utwór ten był śpiewany przez chór łupkowsko-załężański, złożony z internowanych obozu w Łupkowie, przewiezionych następnie do Załęża ${ }^{13}$.

Kierując się w stronę centralnej Polski natrafiamy na obóz kobiecy w Kielcach-Piaskach (utworzony 13 grudnia 1981, istniał do 23 grudnia 1982 roku) Powstało tu kilkanaście utworów: $W$ środku, Moja modlitwa, Wigilia $w$ Kielcach, a także kontrafaktura partyzanckiej piosenki - „Dziś do Ciebie przyjść nie mogę, / Jaszczur zabrał wolność mą”.

Niedaleko Warszawy leży Białołęka. Tu przetrzymywano między innymi pisarzy Tomasza Jastruna, Lecha Dymarskiego, Antoniego Pawlaka, Macieja Zembatego ${ }^{14}$. Obóz był czynny przeszło rok. W ośrodku tym powstały wiersze-kolędy: „Lulajże Jezuniu w tę noc grudniową...” (prawdopodobnie Macieja Zembatego), „Bóg się rodzi, a rodacy po więzieniach rozrzuceni...”, Boże Narodzenie 1981 („Oto nasze wigilijne Dziady”), a także słynny wiersz, przypisywany również Zembatemu „Niech się junta wystrzela / trafi szlag Jaruzela”), znany także jako Hymn ekstremistów.

$\mathrm{Na}$ naszej szczególnej mapie nie może zabraknąć ośrodków Wielkopolski: Poznania, Ostrowa Wielkopolskiego, Mielęcina koło Włocławka. Z tego ostatniego pochodzi modlitwa Ojcze nasz internowanych. Niedaleko Piły w Potulicach mieścił się kolejny obóz. Internowani, spędzający razem wigilię zostawili po sobie Hymn Potuliczników i wiersz Wigilia w Potulicach:

W dzień wigilijny w potulickim lagrze

Internowani przez Pancerną Pięść

Za „Solidarność” ślemy modły nasze

Za prawa ludu, za Ojczyzny cześć.

Pólnocna Polska miała również swoje obozy odosobnienia w Kwidzyniu (byłe województwo elbląskie), Iławie (b. olsztyńskie), Gołdapi i Suwałkach (obydwa b. suwalskie). W Kwidzyniu powstały Pytania o zmierzchu. Obóz w Iławie trwał od 13 grudnia 1981 do 28 czerwca 1982, po jego zlikwidowaniu internowanych przewieziono do Kwidzynia i obozu w Kielcach-Piaskach ${ }^{15}$. W Iławie powstała Modlitwa obozowa, piosenka "Wojtusiu Wojtusiu cóż to za wojenka” oraz Czastuszki iławskie („Posłuchajcie moi mili, jak zadymkę robi rząd”). W Gołdapi, w ośrodku wczasowym pracowników telewizji mieścił się obóz dla kobiet. Wspomnieniem tego czasu jest Goldapska gitara, liryczny wiersz „Na marginesie życzeń Wielkanocnych / Czegóż mam życzyć tej żałobnej wiosny” oraz seria piosenek: Czy pani

\footnotetext{
${ }^{13}$ Ibid., s. 26.

${ }_{14}$ Zob. W stanie, Warszawa 1984.

15 Podaję za autorami antologii Glosy zza muru, op. cit., s. 10.
} 
mieszka sama, Pancerny autobus („Pancerny autobus do Gołdapi gna”). Szczególną popularnością w Gołdapi cieszył się, powstały w więzieniu w Olszynce Grochowskiej hymn Ekstremistka jestem, śpiewany na melodię ludową Eowiczanka jestem.

Ekstremistka jestem

Danaż moja dana

Siedzę sobie w celi

Bom internowana.

Od paru dni miewam

Nieproszonych gości,

Którzy mnie wciąż kuszą

Mirażem wolności.

Na którą powrócić

Latwo jest szalenie,

Wystarczy podpisać

Jedno oświadczenie!

W obozie w Suwałkach, istniejącym od grudnia 1981 do końca marca 1982, śpiewano Hymn internowanych $w$ Suwalkach. Była to jeszcze jedna wersja pieśni My Pienwsza Brygada. Zachowały się także hymny internowanych z obozu w Strzebielinkach i Chełmnie.

Na naszej mapie zabrakło miejsca dla obozów w Nysie, Nowym Wiśniczu, Lublinie, Włodawie, Gęborzewie, Łowiczu, Krasnymstawie, Grodkowie, Kamiennej Górze (istniejącym od grudnia 1981 do kwietnia 1982, mieścil się on w dawnej filii hitlerowskiego obozu Gross-Rosen). Pominęliśmy je świadomie. Nie zachowały się bowiem źródła wskazujące na istnienie „własnych” obozowych pieśni. Internowani, dając wyraz przeżywania wspólnego losu, znali i śpiewali utwory powstałe w innych obozach.

\section{Spectrum socjologiczne}

Okolicznościowa poezja stanu wojennego daje obraz przeżyć ówczesnego społeczeństwa, reakcji na stan wojenny, ludzkich zachowań i postaw, daje obraz dnia codziennego.

Gdy o północy z 12 na 13 grudnia oglądającym na drugim programie TV film braci Taviani Święty Michat mial koguta spiker ogłosił zakończenie programu, nikt nie wiedział, co się stało. Początkowo nawet słowa generała Jaruzelskiego, ogłaszającego w niedzielę stan wojenny, nie były rozumiane. Przejmująca muzyka Chopina, nadawana przez cały dzień, sugerowała, że stało się coś złego. To był „dziwny stan”, jak go określił anonimowy autor.

Dziwny stan - jakby ktoś zabił ptaka

A ty w uszach masz ciagle jego śpiew

Oczy pieką, lecz nie będziesz płakał

„Bo od śmierci silniejszy jest gniew”. 
To już rok? Cały długi rok krótki!

Kiedyś wreszcie wzniósł kark, ruszył w tan

Świat wirował pijany — bez wódki

Skąd więc dzisiaj ten kac - dziwny stan.

Wyjąc przemknął radiowóz na Wilczą

Znów za ścianą ktoś Chopina gra

Nie odzywa się nikt, wszyscy milczą

Żona dzieci, telefon i ja.

W kuchni ogień już zgasł, cieknie kran

Patrzę w ekran milczący i senny.

Ale nie chcę iść spać — dziwny stan

Spiker mówi, że to stan wojenny.

niedziela, 13 XII 1981, wieczorem

Ten utwór, napisany 13 grudnia wieczorem, jest zapisem pierwszych reakcji na dramat nocy grudniowej. Wielu nową sytuację odczuwało tak, jak podmiot liryczny tego wiersza. Uczucie to wyraża metafora ,jakby ktoś zabił ptaka / a ty w uszach masz jego śpiew”. Jest w niej zawarta strata i żal, że minęło coś pięknego, wzniosłego, cennego. Ptak jest symbolem wolności, już wiemy, co jest przedmiotem utraty, żalu i z trudem powstrzymywanych łez.

Przywołany obraz czasu radości i nadziei („kiedyś wreszcie wzniósł kark”, gdy „świat wirował") trwający niestety zbyt krótko, tylko rok, został kontrastowo zestawiony z obecną rzeczywistością. Ewokuje ją muzyka Chopina, złowrogi sygnał radiowozu milicyjnego i cisza wyłączonego telefonu. Milczenie ludzi podkreśla nastrój smutku i żałoby. Wyeksponowany fakt obcości komunikatu spikera — „spiker mówi” zyskuje dodatkowy sens.

Pojawiające się trzykrotnie: na początku, w środku i na końcu słowa „dziwny stan” tworzą ramę kompozycyjną. Aluzja staje się mechanizmem języka poetyckiego — „dziwny stan” to stan wojenny. Autentyzm przeżycia i grozę nocy 13 grudnia oddaje wiersz Noc generałów („Zbudzili łoskotem butów / Kopnięciem strzaskali drzwi”). Grudniowq nocq natomiast to wiersz-komunikat. Dramat zdarzeń wyłania się z przekazu i zestawionych informacji: „wyłamują drzwi”, „wloką na mróz tysiące Polaków”, zapełnione więzienia”, „żrące gazy i SB-owskie pały”, „krew tryska spod gąsienic”. W utworze wyeksponowano uczucie trwogi, rozpaczy, płaczu dzieci, przerażenia.

Odwołane zajęcia dla uczniów i studentów, brak możliwości skontaktowania się z najbliższymi, mieszkającymi w innych miastach w związku z przerwaniem łączności telefonicznej i zakazem swobodnego poruszania się po kraju, zwiększona ilość patroli milicyjnych, wreszcie - obecność czołgów na ulicach, potwierdzały bolesną rzeczywistość, ogłoszoną 13 grudnia. Wiernym odzwierciedleniem nastrojów społecznych jest wiersz Trzynasty grudnia. Poeta oddał wiernie atmosferę, posługując się oksymoronami:

Milczysz, zagryzasz wargi, a serce goryczą broczy

Ugiąłeś się — nieugięty, niezłomny — jesteś złamany 
Próżno wyważać drzwi, rozwalać przeklęte ściany

Milczysz — i krzyk zdławiony płomieniem bije ci z oczu (...)

I tak jeszcze długo do wiosny, i tak jeszcze długo do świtu!

Wprowadzenie stanu wojennego wywołało wśród ludzi uczucia upokorzenia, zdeptania, złamania. Społeczeństwo, które w Sierpniu 1980 roku poczuło po raz pierwszy swoją godność, znów zostało zdegradowane do poziomu sług. Uczucie upokorzenia pogłębia bezsilność i bezradność, świadomość przewagi przeciwnika. Flaga biało-czerwona, jako narzędzie walki w rękach robotnika roku 1981, czyż mogła równać się potędze skierowanej weń lufie czołgu? Decyzja generałów, bezwzględna i niespodziewana, odbierała także nadzieję: „Nad białą trumną Nadziei - mundury w szeregu ponurym". Najtrudniejsze chwile przeżywali Polacy w wigilię i Święta Bożego Narodzenia. List Papieża Jana Pawła II do generała Wojciecha Jaruzelskiego i prośba, by pozwolił spędzić je w nieuszczuplonym internowaniem gronie rodzinnym, nie odniosły skutku. Radość tych szczególnych, glęboko wpisanych w tradycję narodu świąt przesłonił smutek, gdy przy stole wigilijnym zabrakło ojca, brata, syna, matki: „Siedzimy przy skromnych wigilijnych stołach.../ Najlepszych z nami nie ma” - tak problem ujął anonimowy poeta w wierszu Wigilia 81 . Spora ilość utworów, by wymienić tylko niektóre tytuly: Boże Narodzenie '81, Bóg się rodzi (A. D. 1981), Kolęda 1982 r., Wigilia w Kielcach, Zaświecita nam gwiazda, Lulajże Jezuniu $w$ tę noc grudniowa, Życzenia noworoczne eksponuja motyw pogwałcenia pokoju, profanacji świąt i rozdzielenia rodzin. Słowa oskarżenia pod adresem autorów stanu wojennego zostały wypowiedziane w wierszu Wesolych świqt, panie generale:

Wesołych Świąt, panie generale!

Przy ruskiej wódce i ruskim kawiorze.

Ja siedząc sama przy świątecznym stole

Wciąż nasłuchuję, bo o tej to porze

Twoi służalcy mogą drzwi wyłamać,

Mogą opłatek, jak życie znieważyć.

To dzięki tobie jestem dzisiaj sama,

Ty dałeś rozkaz zabronić nam marzyć.

Wiersz jest także świadectwem powszechnego uczucia niepewności, trwogi i obawy o los najbliższych. Dla rodzin zabitych górników święta to czas żałoby. Nawiązuje do tego Ballada górnicza (,siostry twoje w żałobnych sukienkach”).

Jednak życie ma swoje prawa i dzień za dniem upływa nawet bez naszej woli. Zdławiony siłą opór strajkujących zakładów pracy narzucił społeczeństwu postawę przystosowania się do nowej sytuacji. Wewnętrznie nadal odczuwano sprzeciw, a stan wojenny postrzegano jako gwałt zadany narodowi i każdemu z osobna. Tego, co się stało, nie można było zaakceptować.

Społeczeństwo wybiera więc mniej radykalne środki protestu. Jest nim wspomniany już udział w uroczystościach religijnych, żegnanie się słowami „Byle do wiosny!” (hasłem dość popularnym jest także powiedzenie „zima wasza, wiosna nasza”). 
Jedną $\mathrm{z}$ form protestu jest bojkot środków masowego przekazu, niekupowanie gazet, ostentacyjne wystawianie telewizorów do okien lub gromadne wychodzenie na spacer w czasie nadawania dziennika telewizyjnego. Do tej praktyki nawiazuje tekst Spacer telewizyjny. W utworze wskazany jest cel akcji:
Aby było im wiadomo
że dość mamy kłamstw $z$ ekranu
dosyć pałek krat i ZOMO,
dosyć wojennego stanu.

Duże poparcie w społeczeństwie zyskał protest aktorów, którzy odmówili udziału w przedstawieniach i filmach realizowanych przez „reżimową” telewizję. Na długo zniknęli wówczas z ekranu ulubieńcy publiczności i uznani artyści. Ich powrót na scenę nie był sprawą latwą, bojkot niektórym złamał karierę, innym przydał popularności. Odmowa, milczenie, nieobecność były w tych czasach formą walki i znakiem niezgody na politykę faktów dokonanych 13 grudnia. Uznanie dla tej akcji wyraża wiersz Aktorom:

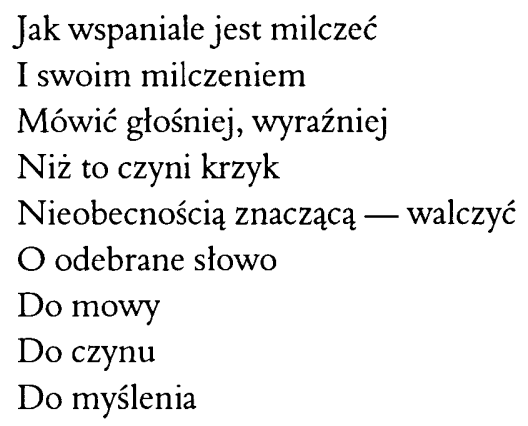

Postawa buntu wobec zastanej rzeczywistości, niezgody na panujące układy, gotowość do walki o prawa i ideały cechuje bohatera romantycznego. Nasz narodowy charakter ukształtował duch powstań, Wiosny Ludów, ideał walki „O wolność naszą i waszą”, występowanie w obronie szlachetnych ideałów. Świadomość współczesnych Polaków wykreował romantyzm ze swoim umiłowaniem wolności, bezkompromisowości i idealizmem. Rzeczywistość 1981 roku wyzwoliła w społeczeństwie polskim postawy romantyczne. Dialektyka narodowego losu w sposób nieoczekiwany zaktualizowała wzory zachowań romantycznych bohaterów. Mamy Wallenrodów XX wieku, organizujących zbiorowe protesty i prowadzących walkę samotnie, jak kolporterzy bibuły. Wobec bojkotu oficjalnej prasy „bibuła” była jedynym źródłem informacji, jedynym źródłem prawdy. Od Sierpnia 1980 notuje się prawdziwą eksplozję wydawnictw podziemnych, tzw. drugiego obiegu. Stan wojenny w poważnym stopniu ograniczył ich rozwój, głównie z powodu konfiskaty sprzętu poligraficznego, maszyn drukarskich, papieru, ale nie załamał niezależnego ruchu wydawniczego. Dekret o stanie wojennym zawiesił wolność słowa, druku, wprowadził zakaz korzystania z urządzeń poligraficznych. Za rozpowszechnianie wiadomości bez zezwolenia cenzury groziła kara od 6 mie- 
sięcy do 10 lat więzienia, za wykroczenia przewidywano karę do 3 miesięcy aresztu ${ }^{16}$. Wydawanie gazetek, pism, a nawet książek było więc związane z dużym ryzykiem. Wielu ludzi podjęło jednak to wyzwanie, tak rozumiejąc swoje zadanie wobec okrutnego czasu i innych ludzi, spragnionych prawdy, tak prowadząc swoją walkę z systemem, którego nie akceptowali. Mottem kolportera nielegalnych publikacji są słowa pomieszczone w wierszu Piosenka kolportera bibuty: „Na wolność to wkrótce wymienisz / Przeczytaj. Przepisz. Nie niszcz”. Autorzy tekstów oraz ci, którzy odbijają je na powielaczu, w konspiracji mają świadomość, że ich działanie, jako swoisty znak czasu, przejdzie do historii:

\section{SB sczeźnie i ZOMO zaginie \\ Generałów przegonią do koszar \\ Do historii zaś wejdzie na zawsze \\ Bibuła i wojenny kolportaż}

Jest także coś z romantycznego traktowania swojego działania w szczególnych momentach historii jako misji i posłannictwa. Odbijanie ulotek na powielaczu było również wyrazem przekory niepokornego społeczeństwa. W takiej humorystycznej konwencji problem ten jest przedstawiony w utworach Ballada o chtopcu, który wyróst z butów (do procederu rozprowadzania ulotek została zaangażowana cała rodzina, także babcia 92-letnia, której ze względu na wiek ZOMO nie zatrzymuje) oraz Przy powielaczu („Przy powielaczu wesoło mija czas / Przy powielaczu wpaść może każdy z nas").

Oazą wolności, instytucja, której wiarygodność można było uznać i przekazywane informacje przyjąć za prawdziwe, było też Radio Wolna Europa (również Głos Ameryki).

$$
\begin{aligned}
& \text { „Solidarność” siedzi i to dużo chłopa } \\
& \text { Jeszcze nam została Wolna Europa } \\
& \text { („Trzynastego grudnia roku pamiętnego”) }
\end{aligned}
$$

I choć Radio Wolna Europa powstało jako element „zimnej wojny” (wśród członków założycieli byli C. D. Jackson, gen. Lucius Clay, Joseph C. Grew; wszyscy wywodzili się ze sztabu psychologicznego alianckiej kwatery głównej - SHAPE's Psychological Warfare Staff in World War $I^{17}$ ), przez ponad trzydzieści lat było także radiem polskim. Związani z nim byli Zdzisław Najder, Jerzy Giedroyc - szef paryskiej „Kultury”, Marek Łatyński, Roman Stefanowski i inni. Przez długie lata, zwłaszcza w okresie stanu wojennego, wokół radia skupiała się cała rodzina, by posłuchać wiadomości. Było w tym zachowaniu coś z rytuału, obrzędu. Odszukanie stacji było nie lada wyczynem wobec powszechnej wówczas praktyki zagłuszania fal. Nawiązuje do tego Ballada o chtopcu, który wyróst z butów: „Moja mama od

${ }^{16}$ Dekret o stanie wojennym, Dz. U. PRL nr 29 z 14 grudnia 1981 r.

17 Podaję za: R. Stefanowski, Wolna Europa od kuchni, „Zdanie” 1998 nr 1-4, s. 81. Zob. także: M. Łatyński, Ogród Angielski. Wspomnienia z Radia Wolna Europa, Lublin 1997 oraz G. R. Urban, Radio Free Europe and the Pursuit of Democracy, London 1997. 
zmroku do brzasku / trzeszczy radiem antenę mnąc w dłoni..." Roli RWE w tamtym czasie nie sposób nie docenić.

Znaczną część zachowanych utworów stanowią „głosy zza muru”, listy pisane z więzień, ośrodków odosobnienia do rodziny, najbliższych, przyjaciól. Antologia Anonimowa poezja stanu wojennego notuje List ukrywającego się dziatacza NSZZ „Solidarnośc” do żony, Noc generatów — zbiór poezji wojennej zamieszcza List do matki, List do żony, Piosenkę dla córki, Piosenkę dla syna, także Gryps. Wspólnym motywem tych utworów jest tęsknota za najbliższymi, troska o swój i ich los, ale także przekonanie, że walczyło się o słuszną sprawę. Liryczne wyznania: „Nie mam teraz czasu dla Ciebie” (Piosenka dla córki), "Czytałbym Ci bajeczki na głos”, "Nie pójdziemy na spacer do lasu" (Piosenka dla syna) potwierdzają ludzki, a zarazem jednostkowy wymiar dramatu internowanych. Byli to zwyczajni, prości ludzie, siłą oderwani od swych rodzin za wierność swoim przekonaniom, skazani na poniewierkę i prześladowania, bo chcieli godnie żyć w wolnym kraju.

Ojca nigdy się nie wypieraj

Bo cierpię nie za zbrodnię żadną

Nie zgodziłem się tylko wybierać

Między mym honorem a hańbą

Słowa te (z Piosenki dla syna) brzmią jak przesłanie dla następnych pokoleń. Nie wszyscy Polacy zdali pozytywnie egzamin z wyboru pomiędzy honorem a hańbą; ci, którzy wybrali honor, zapłacili za to internowaniem. O tym należy pamiętać także w czasach, które przed człowiekiem nie stawiają takiego wyboru. Antologia Głosy zza muru przynosi między innymi wiersze Sto dni, Przeliczanka opisujące zwykły dzień więźnia, specyficzny więzienny ceremoniał: rano „klawisz zagląda czy się nie wściekłem”, potem „ogłupiający spacer” i zachowania ludzi: „twarze zmęczone apatia”. Podobne obrazy występują w tomiku Zapomnisz...?, w wierszach: Spacer więźniów, Grypsy, Z calym szacunkiem, Spotkanie, Wychowawcy („Starzy chłopcy znów mamy wychowawców”) oraz utworze Kielczanki (Marii Przybylskiej) Cela 513. Z okazji 8 marca kobietom, opuszczonym przez swoich mężczyzn, został dedykowany wiersz Kobietom internowanych:

\section{Podaję Ci różę zza krat}

Różę niewoli i poniżenia

Przyjm ją i razem zmieńcie ten świat

Wyrwijcie zęby krat więzienia.

Los internowanych podzielił także przywódca Niezależnego Samorządnego Związku Zawodowego „Solidarność” - Lech Wałęsa. W wielu tekstach zostało zawarte przywołanie tego faktu: "Zamknęli nam Lecha” (Trzynastego grudnia roku pamiętnego). Ma swe wezwanie Lech Wałęsa w Litanii: „Przez uwięzienie sługi Twego Lecha...”, w Rocie otrzymał zapewnienie: „Nie rzucim Cię Wałęso nasz”. Dedykowano mu Życzenia świquteczne dla Lecha Watęsy, wiersz, w którym przekazywane są słowa otuchy, poparcia i solidarności: 
Trzymaj się Leszku. Dymy

Stoczni, kopalń hut myślą ogarnij,

My z Tobą solidarni,

Przetrwamy i zwyciężymy.

Zachowała się też Modlitwa Lecha Watęsy w więzieniu.

Lech Wałęsa, elektryk pracujący w Stoczni Gdańskiej, przywódca ruchu związkowego, uczestnik obrad Okragłego Stołu, laureat Pokojowej Nagrody Nobla, późniejszy prezydent Rzeczypospolitej stał się symbolem tamtego czasu, „Solidarności”, dążeń Polaków do niezależności, walki z reżimem. I choć późniejsza działalność polityczna naruszyła jego legendę, Lech Wałęsa pozostanie w świadomości spoleczeństwa polskiego, zapewnił też sobie miejsce w historii.

W tomikach okolicznościowej poezji stanu wojennego znajduje swój wyraz uczucie dezaprobaty, gniewu i oburzenia dla stanowiska armii polskiej, która została wykorzystana do thumienia buntu społeczeństwa i strajków w zakładach pracy. W wierszach podniesiono problem zdrady, hańby, sprzeniewierzenia się chlubnej tradycji oręża polskiego i splamienia honoru żołnierza. Na uwagę zasługują wiersze-apele, jak ten pod tytułem Do żotnierza:

Żołnierzu polski, zatrzymaj swe kroki

Żołnierzu polski, opuść broń

W przeciwnym razie ogarną nas mroki

W rozpaczy pogrąży się każdy dom

Dramatyzm zdarzeń wyrażono za pomocą pytań retorycznych: „Komu ty służysz, synu Polski?”, „Kogo osłaniasz, wnuku górnika?”, „Kiedy rodziców swych zaczniesz bronić?” Również w wierszu Do żotnierza $L W P$ naczelną figurą jest pytanie retoryczne.

Z kim się będziesz żołnierzu bił

$Z$ własnym ojcem, synem czy bratem?

Za to tylko, że chcemy żyć

Ty masz zostać sędzią i katem?

Anonimowy poeta oskarża polskiego żołnierza o ślepe, bezrozumne wykonywanie rozkazów, zwrócenie się przeciwko narodowi. W roku 1981, wraz z postawą Ludowego Wojska Polskiego, które walnie przyczyniło się do wprowadzenia w Polsce stanu wojennego, upadł mit żołnierza-obrońcy. Wojsko polskie zostało skompromitowane.

A już najbardziej uniwersalny jest żołnierz

$\mathrm{z}$ żołnierzem to można zrobić

dosłownie wszystko

— tak ironicznie, a nawet z pogardą wypowiedzial się Jan Poznański w wierszu Grupa operacyjna. Poza wewnętrznym sprzeciwem tych żołnierzy, którzy nie zaakceptowali wprowa- 
dzenia stanu wojennego, w wojsku polskim w 1981 roku nie odnotowano przypadku buntu ani precedensu odmówienia udziału w akcji pacyfikacyjnej zakładów pracy. Dzieje oręża polskiego w okresie stanu wojennego zapisały niechlubną kartę. W wierszu Żolnierzu!, stylizowanym na rozkaz podpisany przez generała Jaruzelskiego, padają słowa-świadectwa: „Górnikom z kopalni Wujek: Cel! Pal! (...), Naukowcom i profesorom — pięścią w twarz! (...) Studentom na Uniwersytecie - pałą w łeb! (...), Ekstremistom z "Solidarności” kolbą w ryj!" W jednym z utworów polski żołnierz otrzymał przydomek „żołnierz podłości” (Żotnierz podtości z tomu Zapomnisz...?)

Satyra stanu wojennego nie oszczędza też oddziałów ZOMO. Im poświęcono wiersze: Chtopaki z ZOMO, Jak trudno być zomowcem, My się ZOMO nie boimy i Zomomotywa.

Ale główne ostrze oskarżenia zostało skierowane w generała Wojciecha Jaruzelskiego i grupę jego współpracowników. Formą napiętnowania było zasłużenie sobie na wierszyk.

Niechaj więc wie pochlebców klika,

Że może trafić do wierszyka (...)

Za wszystkie świństwa razem wzięci

Pozostaniecie nam w pamięci.

$$
\text { („Pewien odważny pan generał”) }
$$

I tak utworów na własny temat doczekali się Jerzy Urban, Mieczysław Rakowski, Czesław Kiszczak, Albin Siwak, Stefan Olszowski, Kazimierz Barcikowski, Władysław Loranc. Im poświęcono szopkę Gniazdo wronie, Sejm WRONy, Sejm się bawi. Wytknięto także tych, którzy udzielili poparcia akcji Jaruzelskiego. Bohaterami anonimowej satyry stali się minister Krasiński, poseł Janusz Przymanowski, pisarze Wojciech Żukrowski i Jan Dobraczyński, aktor Janusz Kłosiński i spikerzy telewizji: Irena Falska, Grzegorz Woźniak, Marek Tumanowicz, Witold Stefanowicz. Najbardziej znienawidzonym dedykowano epitafia:

Stąd można wykopać Siwaka Albina

Brakujące ogniwo teorii Darwina

Znaczną grupę tekstów stanowią utwory dedykowane Wojciechowi Jaruzelskiemu. Jego naród uznał za sprawcę wszelkiego zła, swoich upokorzeń, cierpień, prześladowań, osamotnienia, oddzielenia od najbliższych. Jego nazwał „pachołkiem moskiewskim, „ślepcem”, „jaszczurem”, „ślepowronem”, „Judaszem”, „Pinochetem”, „synem Stalina”:

Ty sługo kremlowy, lokaju sowiecki

Ty zbóju wojskowy, pomiocie radziecki,

Ty mówco obłąkany, nadęty bufonie -

Za naród sprzedany piekło cię pochłonie.

(Maciej Zembaty, Bluzgi)

Pytanie retoryczne: „Dokąd nas ślepcze prowadzisz...?”, zadane w wierszu Ślepiec, pozwala rozpatrywać prowadzoną przez generała politykę $\mathrm{w}$ kategoriach dziejowej pomyłki 
i strasznego błędu. Nie bez znaczenia jest poszukiwanie analogii do kart narodowej historii i przywołanie obrazu kibitek wiozących Polaków na Sybir oraz transportu polskich oficerów podczas II wojny światowej do Katynia. Główny zarzut postawiony generałowi dotyczył wywołania wojny $z$ własnym narodem i skierowania na bezbronnych czołgów. Na generała Jaruzelskiego spada też odpowiedzialność za śmierć górników, sprofanowanie munduru polskiego żołnierza. Jego oskarża się o zdeptanie ideałów i marzeń o godnym życiu. List otwarty przynosi kolejne zarzuty: „Zhańbiłeś honor, sztandar, godło”, „Zdradziłeś robotniczą klasę". Ironiczne podziękowania dla generała przynosi wiersz Do generała, znany też jako Naród dziękuje ci generale:
Za połamane pałką kości
Za koszmar walki brata $\mathrm{z}$ bratem
Za nienawiści siew i złości
Za to, że żołnierz stał się katem
Za znów zdławiony świt wolności
Pomnik swych zasług wzniosłeś trwale
Naród dziękuje ci, generale.

W większości tekstów pojawia się motyw zdrady.

Gdzie twa ojczyzna, zapyta cię człowiek

Bo ta nad Wisłą ciebie się wyrzeka (...)

Twój dom jest w Moskwie albo za Uralem

(Do generata)

Jaruzelskiego porównuje się więc do Judasza, który za zdradę otrzymał zapłatę w srebrnikach - wiersz Bożych Narodzin zbezcześiteś swięto. We wszystkich utworach, których bohaterem jest Wojciech Jaruzelski, dominuje przekonanie, że za swój czyn zostanie pociągnięty do odpowiedzialności i stanie przed trybunałem. Ta wiara, wypływająca niejednokrotnie $z$ ludowej mądrości, potwierdzanej także przez literaturę romantyczną (nie ma winy bez kary) pozwalała przetrwać, dodawała sił, stwarzała nadzieję.

Większość utworów kończy się więc optymistycznie:

Przejdzie sroga zima, przyjdzie ciepła wiosna

Powstanie znów Polska - wolna i radosna

$$
\text { (Jaruzelka) }
$$

Topos wiosny w polskiej kulturze i literaturze ma szczególny sens. Jako symbol odrodzenia, powstania, zerwania z mroczną, „zimową” przeszłością ewokuje sny o wielkiej, wolnej Polsce. Spopularyzowany przez Żeromskiego, w roku 1981 ponownie się zaktualizował.

Przeświadczenie o dziejowej sprawiedliwości jest głęboko zakorzenione w świadomości Polaków. Na nim opiera się kodeks moralny społeczeństwa polskiego, szczególnie wraż- 
liwego na dziejącą się krzywdę, toteż w wierszach przewiduje się niechlubny koniec dla autora stanu wojennego:

Wkrótce generale sczeźnie twoje imię

Polska nie zginęła i nigdy nie zginie

Rzeczywistość okazała się jednak inna od tej przewidywanej w utworach literackich. Od wydarzeń tamtej nocy grudniowej minęło dziewiętnaście lat. Do dziś wprawdzie stan wojenny potępiono, także w ustawie sejmowej, ale mimo trwających procesów wyroki nie zapadły.

Upływający czas zaciera kontury wydarzeń, rozmywa granice odpowiedzialności, pogrąża w mroku niepamięci spory i polemiki, zagłusza wyrzut sumienia, ucisza ból, a przecież „pamięć jest najskuteczniejszą bronią” - jak stwierdzili autorzy antologii Zapomnisz...? we wstępie.

Literatura polska zawsze była zbiorową pamięcią narodu. Taką funkcję pełnią też tomiki poezji stanu wojennego: nakazują nie zapominać.

Zapomnisz czym był dla ciebie

Okres szesnastu miesięcy

Zapomnisz, żeś był odważny,

Żeś słuchał głosu sumienia.

Zapomnisz pragnienia wolności,

Godności ludzkiej,

Poczucia jedności z sąsiadem.

Zapomnisz, że Polska

Miała pozostać Twoim krajem.

Zapomnisz

kim był

co czynil

co chcial

Tobie i innym podarować

Gdański elektryk

Lech Wałęsa

ZAPOMNISZ...?

(4 II 1982) 